\title{
650 years of the office of
}

\section{Justice of the Peace/Magistrate}

\author{
by Alan Lambert
}

$\mathrm{T}$ he idea of trussing up a defendant and tossing her into the local duckpond to see if she floated is far removed from the structured system of sentencing guidelines we have today, but reliance on such "divine providence" was at the heart of the law as Britain emerged from the Middle Ages. This period was violent and bloodthirsty, and there were no laws or rules to protect prisoners. Torture was seen as a totally legitimate means of extracting confessions or the names of accomplices. And one such method used was the ducking stool, which was specifically designed for women. The crimes which deemed such a punishment were prostitution and witchcraft, and the ducking stool was seen as a foolproof way to establish whether a suspect was a witch. If she floated it was deemed that she was in league with the devil, rejecting the "baptismal water." If she drowned, she was deemed innocent.

\section{RICHARD 1}

The part played by magistrates in the judicial system of England \& Wales can be traced to the year 1195, when Richard 1 commissioned certain knights to preserve the peace in unruly areas. They were responsible to the King for ensuring the law was upheld. They preserved the "Kings Peace" and were known as Keepers of the Peace, but their role does not appear to have included administering justice.

\section{THE PLAGUE}

A statute of 1327 appointed "good and lawful" men in every county to guard the peace and these were referred to as Conservators or Wardens of the Peace, and the early signs of local justice. However, the arrival of the Black Death in 1348 devastated the population and wrecked much of the established social order at a local level. The breakdown of society resulted in virtual gang warfare in parts of England and brought about reversion to central control with Parliament issuing writs to local sheriffs, officials and individuals extending the role of those guarding the peace. They were given additional powers to hear and determine cases before them and to impose punishment.

\section{THE STATUTE OF 1361}

The strengthening of the powers given to the guardians of the peace resulted in the imposition of unjust punishments and excessive fines which upset much of the population. As a consequence the powers of guardians were restricted to local individuals with jurisdiction limited to their own county.

The current role as justices of the peace has its foundation in the statute enacted by Edward III in a Parliament held at Westminster in 1361 on the Sunday before the feast of the convention/conversion of St Paul. (Today, the Christian calendar celebrates this feast on January 25 each year.) Research shows that "the first Commissions of the Peace addressed to justices were sealed on 20 March 1361." Most of the principles enshrined in the statute hold good today, and include what we now know as the power to bind people over to be of good behaviour. The statute also refers to the need for fines to be "reasonable and just".

The Act of 1361 also provided that JPs should meet to conduct local business four times a year. This was the origin of Quarter Sessions which continued until replaced by Crown Courts in 1972.

JPs are often referred to as the great unpaid. In fact, under an Act of 1389 the early Justices received a "subsistence allowance" of four shillings a day. This appears to have lapsed, presumably because for centuries most JPs were well-to-do landowners who would not bother about expense accounts. As landed gentry, they often prioritised laws that favoured their own interests, for example, taking a tough stance on poachers.

Following the appointment of Justices of the Peace (Custodes Pacis) in each county, the sheriff, under-sheriffs and gaolers were stripped of the powers they held as guardians, but it was not long before concerns were expressed over the powers held by the new justices. Various objections were raised over what they should or should not deal with, their method of appointment and other issues, but King Edward held firm; he maintained the terms of the statute and responded that suitable people should be named in Parliament, and then he would assign whom he pleased. The foundations for our current system were firmly laid. 


\section{FIFTEENTH AND SIXTEENTH CENTURIES - MORE DUTIES}

During the early fifteenth century, JPs acquired a reputation for dealing with the problems of the day effectively and by the end of the century they operated all local government administration. In 1461 their judicial supremacy over sheriffs was confirmed when all presentments and indictments previously taken at the "sheriff's tourn" had to be taken before the justices. Increasing trade and industry added to their responsibilities with regulatory functions concerning the quality of craftsmanship and prevention of fraud.

JPs had other responsibilities in these times, including supervising silver merchants, wages and prices. Bail powers had been growing since 1444, but were vague. In 1483/4 justices were given power to bail prisoners on suspicion of felony, although some abuses led to a later Act of 1487, which stipulated that at least two justices must be present to grant bail.

In coastal areas JPs had additional duties relating to the fishing industry in regulating prices and in the packing of fish. They also policed an Act which prohibited the import of wine except in English, Welsh and Irish ships.

Religion and poverty also had a major impact on the work of JPs. The dissolution of the monasteries (1536-41) left many poor people without help and vagrancy became a wide-spread problem. In 1572, JPs were given a specific role to help the poor in their community. Magistrates became responsible for collecting poor rates - a compulsory tax paid by local landowners to alleviate poverty.

In 1576, magistrates were granted the power to build "Houses of Correction" to lock up criminals caught by village constables, who were also unpaid members of the community.

And, after years of Catholic and Protestant wrangling, a new requirement was introduced in 1579 for all magistrates to swear fidelity to the Church of England.

\section{SEVENTEENTH CENTURY - MORE RESPONSIBILITY}

The 17th century brought vast changes, both political and religious, and few were affected more than magistrates. Initially responsible for investigating, prosecuting and sentencing felons, by 1603 they had trebled in number and 176 extra statutes meant little escaped their powers. They had the unenviable task of enforcing the constant religious changes, and were empowered to monitor church attendance to enforce the Book of Common Prayer, under penalty of life imprisonment for a third-time offender. Once Mary returned the country to Catholicism JPs played their part in burning 273 Protestants. When policy reversed again under Elizabeth JPs punished Catholics for not attending church.
As the century unfolded, local government devolved to justices. In addition to controlling hunting rights, vagrancy and licensing of ale houses, they became responsible for road repairs and redeeming English sailors from Barbary pirates. Their authority extended to apprenticeships and prices, sales of grain, butter, cheese and flesh, and ensuring nobody sold meat on fish days.

The social make-up of the magistracy also began to change, with fewer noblemen and more esquires. The role of the JP also expanded to cover more aspects of criminal law. This change meant a handbook about the duties of justices soon ran to mare than 700 pages.

One of the controversial ordinances during this period was the Marriage Act 1653, which said only marriages conducted by a JP would be recognised by the State. This was later repealed.

\section{THE CIVIL WAR}

King James held magistrates in high esteem and considered them to be "the King's eyes and ears in the country". However, under Cromwell, it is said that JPs' authority sank to a lower ebb than at any time in their history. Although at least half of the Members of Parliament were also JPs, the magistracy was deeply divided during the Civil War. Under Cromwell many magistrates were replaced by lesser gentry, tradesmen and merchants, only to be replaced themselves with the Restoration of Charles II in 1660.

At this point, I must disclose a vested interest. Major General John Lambert, in effect number 2 under Cromwell, was a JP in addition to his many other titles and distinctions. I've yet to establish if we are related, but as he died in prison at Plymouth, I doubt that he left any form of inheritance that might pass my way.

\section{EIGHTEENTH CENTURY - POWER AND DUTIES}

Although the most serious offences of the day were sent to Assize Courts, up to the middle of the century JP's could sentence offenders to hanging. They could also sentence to transportation to North America and the Caribbean, to whipping and the stocks, and to fines.

Imprisonment was used mainly for debtors. However, offences often never came to court. The law-enforcers, the constabulary, were members of the public required to do the job part-time and temporarily, so their commitment was variable. Routine violence was tolerated, and when they did come to court they were often dealt with by a fine or a bind-over. On the other hand, the penalties for theft were draconian - the theft of goods worth over one shilling from the house of the owner was a hanging matter.

The major social problem was poverty. Magistrates had to seek work for the unemployed and control food prices. They paid employers to take on apprentices to ensure 
children did not grow up to be a drain on parish finances. Although it was a very different magistracy, the dedication to unpaid public service was very much in evidence.

Parliamentary government came to the fore with Robert Walpole as the first de facto "prime minister." In 1700, all MP's who were not already justices were so appointed. It was on justices that the main burden of local administration fell; more so than ever before, since not only judicial and peace-keeping, but everything from apprentices, the upkeep of gaols, bridges and highways, the collection of window taxes, to Poor Law administration. This aspect was very demanding. Numerous schemes to address the plight of the poor were tried, but generally found wanting. However, the unpaid endeavours of local justices are now seen as having laid the groundwork for enduring local government structures.

\section{HENRY FIELDING 1707-54}

The Poor Laws undoubtedly contributed in pushing the poor towards London, putting some areas under considerable pressure, with the resultant opportunities for new justices to engage in corrupt practices by seeking financial rewards for their services.

This led to Middlesex justices being described in the House of Commons as "the scum of the earth". In addition, the Game Laws, introduced, administered and sentenced by those with a vested interest, led to some outrageous abuses, with a high proportion of prisoners and transportees there because they had broken these highly restrictive laws.

However, through these difficult times, an alternative was found in the form of a professional or stipendiary magistrate. One of the forerunners (subsequently appointed as Chief Magistrate), was the dramatist, Henry Fielding. He published a pamphlet entitled An Inquiry into the Causes of the late Increase of Robbers, etc which called for sweeping changes in the laws and in the way they were enforced. Today these proposals would not appear to be anything special, but by 1753 several of these reforms had been put into practice and Henry helped break up several large gangs by offering money and immunity to those who turned in their fellow criminals.

Perhaps the most important result of his ideas was the reform of the police. Henry had the power to investigate crimes, question suspects, and then either release them or order them held for trial. He was successful enough to be given the title of Chief Magistrate. He was, in fact, what we today would call a chief of police-except that London of the 1750's had no organized police at all!

Imagine a city of over half a million people, terrible slums, a high crime rate, and no real police. The few parish constables were chosen by lot, much as we choose juries today, to serve for one year. Most paid substitutes to take their place, and many of the substitutes were as dishonest as the criminals they were supposed to control. Most of the rest, along with the night watchmen, were too disorganised, too feeble, or too frightened of the powerful street gangs to be of any use.

Henry Fielding tried to change all this. He drew up plans for controlling crime, turned his house in Bow Street into a kind of police station, and hired a few of the best constables to serve as more or less permanent police officers. It was as a direct consequence of this activity that Home Secretary, Sir Robert Peel, was to form the Bow Street Runners, Britain's first professional police force. The runners tended to be London born and bred; they knew the people, the ghettos, the pubs and the brothels where people could be found. They didn't flinch from serving notices, warrants or summonses and they were effective in solving crime.

Henry was also directly responsible for improvements in record-keeping, founding what was later to become the Criminal Record Office of Scotland Yard.

\section{THE BLIND BEAK OF BOW STREET}

Due to failing health, Henry Fielding was forced to retire in 1754 . The position, which would become known as Chief of the Metropolitan Police, was offered to his blind half-brother. John Fielding accepted it and held it until his death in 1780 . John immediately set out to put Henry's plans to work.

Within two years, having refined the runners into the first truly effective police force for London, they had broken up most of the gangs of street robbers. John then organised a horse patrol to combat the mounted highwaymen who prowled the roads leading to and from London. He set up systems of rapid communication and published descriptions of wanted criminals and stolen goods. We take these things for granted now, but the Fieldings were the first to think of them.

John's main skills were in questioning witnesses and suspects. Usually he left the legwork to his runners. But sometimes he investigated cases personally. When, in 1763, Lord Harrington's house was robbed of more than $£ 3,000$ worth of silver, gold, and jewels (nearly one $£ 100,000$ in today's money!), John investigated the theft personally. Using one of his helpers for his eyes, he spent the whole day and most of the night examining and questioning. He determined that what was made to look like a burglary was really an inside job. His suspicions fell on a servant, who later confessed.

Elementary? Perhaps. But this was more than one hundred years before the first Sherlock Holmes story was written. About this time John was knighted for his services and became Sir John Fielding. The common people, though, gave him another title_-"The Blind Beak of Bow Street" ("beak" was the 18th century slang for anyone in a position of authority.) He was renowned for allegedly being 
able to recognise 3,000 criminals by the sounds of their voices.

A contemporary described Sir John as wearing a black bandage over his eyes and carrying a switch, which he flicked in front of him as he entered or left his courtroom. He was strict with hardened criminals and was responsible for sending many men (and some women) to the gallows. But he was lenient with young people, especially first-time offenders.

\section{BOW STREET MAGISTRATES' COURT}

The most famous magistrates' court in England for much of its existence, Bow Street Magistrates' Court was located in various buildings on Bow Street in central London close to Covent Garden throughout its history. It was first established in 1740, when Colonel Sir Thomas de Veil, a Westminster justice, sat as a magistrate at his home at number 4 Bow St. In its later years the court housed the office of the Senior District Judge (magistrates' courts), who heard high profile matters such as those relating to extradition or involving eminent public figures. In 2004 the court was put up for sale, and sale was agreed to an Irish property developer for conversion into a boutique hotel. The court closed its doors for the last time on July 14, 2006, when all cases were transferred to the City of Westminster Magistrates' Court.

The final case was that of Jason John Handy, a 33-yearold alcoholic-vagrant who was accused of breaching his anti-social behaviour order. He was given a one-month conditional discharge. Ironically, this was an illegal sentence as conditional discharges are not available for ASBO breaches. The unfortunate Mr Handy was therefore detained to be re-sentenced by another court. Other cases on the last day included beggars, shoplifters, illegal minicab drivers and a terrorist hearing - the first of its kind — in which a terror suspect was accused of breaching his control order. Other famous defendants appearing at Bow St. include Dr Crippen, the Kray Twins, Emmeline Pankhurst and General Pinochet.

\section{NINETEENTH CENTURY REFORM}

In 1800 the magistracy was part of "the establishment", and they were relied upon by the govt. They were authorised to try workers accused of forming trade unions to raise wages and reduce hours, and in 1825 to try workers accused of molesting and obstructing non-unionists. Magistrates were also responsible for maintaining public order by reading the Riot Act 1715, commanding a crowd of 12 or more people to disperse, and calling for armed assistance if it had not done so within an hour.

After the Peterloo Massacre, when magistrates used cavalry to disperse a crown of 60,000 people in Manchester, leading to about 20 deaths and 400 injuries, magistrates became more cautious, and during the political crisis of 1830-32 sometimes read the Act too late, inadvertently allowing mobs to loot the centres of Bristol, Derby and Nottingham. During this time, magistrates came in for a great deal of criticism. They were too few in number (in 1832 only 5,131 and one in four were in holy orders), they were too privileged, had too many powers that were not fairly applied, and were in danger of losing the confidence of the articulate upper middle class. As a result reform began to take shape, and many of their administrative powers were removed. The selection process was also changed by virtue of the Municipal Corporations Act 1835, with the Lord Chancellor taking charge of appointments. This led to the magistracy being less partisan and exclusive, and it had been provided with a new source of law and order through the appointment of Chief Police Officers throughout the counties.

\section{EARLY TWENTIETH CENTURY - MORE CHANGES}

A change in the law in 1919 paved the way for women to become JP's. Within the first year at least seven women were appointed as magistrates; within five years there were more than 1,200 female JPs. Today, just over half (50.8\%) of magistrates are women.

In 1920, the Magistrates' Association was founded. The Association encouraged its members to undertake basic training immediately after appointment and to keep up with changes in law and procedure. In 1962 the Association received a Royal Charter and a coat of arms bearing the motto Ratione and Consilio (by reason and sound judgment).

One of the most outstanding developments during the early 1900's was the establishment of special courts (Juvenile Courts) to deal with the problems of children and young persons, where the care and protection of the child was paramount. An Act of 1933 remains the principle piece of legislation governing juvenile courts today, or Youth Courts as they are currently known.

\section{LATE TWENTIETH CENTURY: THE CROWN PROSECUTION SERVICE, EUROPEAN UNION, AND MAASTRICHT TREATY}

The Magistrates' Court Act 1952 was an attempt to consolidate the jurisdiction, practice and procedures of the magistrates' courts. The most important change brought about by the Act was to repeal the Summary Jurisdiction Act 1879, which, in essence, had stated that a defendant should be found guilty as a matter of course unless he could prove otherwise. Therefore, from 1952, the presumption of innocence was maintained in summary trials as well as trials by jury. Concern over the variation in sentences passed by different benches was also addressed when compulsory judicial training was introduced in 1966. For many decades, Petty Sessions, as they were known, where JPs presided and dealt with the more minor offences, were often referred to as Police Courts. The police guarded the 
doors, put prisoners in the dock, acted as prosecutors and provided the evidence. Perhaps it was understandable that this gave rise to much criticism, and in 1985 the Crown Prosecution Service was established, to introduce an independent element into the prosecution and judicial decision-making process.

An alternative to short-term custodial sentences was introduced in the form of Community service orders, where offenders could be ordered to perform unpaid work in the community. The breathalyser, the $70 \mathrm{mph}$ speed limit, and the compulsory wearing of seat belts were all measures introduced in this period, leading to a radical change in public attitudes.

On January 1, 1973, the UK joined the European Economic Community. The Maastricht Treaty in 1992 made it clear that Member States were bound by its terms. The Human Rights Act in 1998 meant that the European Convention of Human Rights would become incorporated into domestic law, with far-reaching consequences for all, including JPs, which continue today.

\section{WHAT DOES THE FUTURE HOLD?}

Throughout our 650 years, the role of the magistrate has been under constant review and scrutiny. Perhaps it is a sign of the resilience of that office, both in terms of adapting to change and also facing the challenges that constantly arise, that unique office still holds good. Various recent studies have been conducted into various aspects affecting the work of magistrates. A strong conclusion to emerge from research commissioned by the then Home
Secretary, Jack Straw in 2000, concluded: "We doubt that any suggestion that the role of Justice of the Peace be eliminated or greatly diminished would be widely understood or supported".

During 2011 we have seen the closure of many magistrates' courts and the requirement for each county or region to operate within in a much leaner framework. In addition to the impact of global financial difficulties, this has largely been brought about by a drop in the number of cases coming before the courts, with an increased number of lesser offences being dealt with out of court, either by way of fixed penalty or conditional cautioning. Most magistrates would urge caution in not taking things too far by applying this methodology to unsuitable offences and offenders who should really come before the courts.

The magistracy in England \& Wales and the UK is unique, as the only lay judges in the world with the power to sentence people to prison. Over the years many have predicted the demise of the magistracy. Indeed, that was something I put to the Lord Chief Justice, when I had the opportunity to meet him at the Supreme Court in London. I said there were times when I and some of my colleagues felt like an endangered species. His reply was brief and to the point. Where will they find 30,000 volunteers to deal with 95 per cent of all cases coming before the court, and what is more, do it for nothing?

Here's to the next 650 years!

Alan Lambert JP 